Jurnal Keuangan dan Perbankan, 22(2):321-334, 2018

http://jurnal.unmer.ac.id/index.php/jkdp

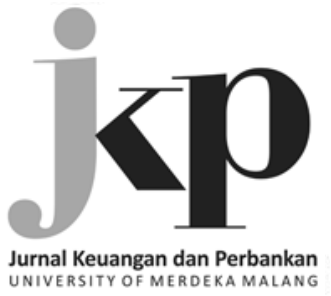

UNIVERSITY OF MERDEKA MALANG

Bella Nursyarifa Rochmadhona (Indonesia),
Tarsisius Renald Suganda (Indonesia), Sendy Cahyadi (Indonesia)

\title{
The Competitive Advantage between Intellectual Capital and Financial Performance of Banking Sector in ASEAN
}

Article history:

Received: 2018-04-02

Revised: 2018-04-28

Accepted: 2018-05-05
Bella Nursyarifa Rochmadhona, Tarsisius Renald Suganda, Sendy Cahyadi

Department of Accounting Faculty of Economics and Business Universitas Ma Chung Villa Puncak Tidar N-01, Malang, 65151, Indonesia

$\triangle$ Corresponding Author: Bella Nursyarifa Rochmadhona: Tel +62 8123579897

E-mail: nursyarifa@gmail.com

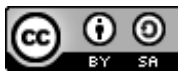

This is an open access article under the CC-BY-SA license

\section{Abstract}

This research aims to examine the mediating effect of competitive advantage in the relationship between intellectual capital and financial performance of the banking sector in five ASEAN countries. Furthermore, this research analyzes the differentiation level of intellectual capital using its components namely human capital, structural capital, and relational capital measured by Extended VAIC Plus (E-VAIC+). This research using partial least square method to test the mediation effect and ANOVA to test the differentiation level of intellectual capital on the banking sector in five ASEAN countries. The results show intellectual capital has a positive effect to financial performance and competitive advantage, competitive advantage has a positive effect to financial performance, and there is a different level of intellectual capital in Indonesia, Laos, Vietnam, Philippines, and Thailand. These findings support the resource-based theory which asserts that a unique set of resources that are owned and controlled can make the company have superior sustainable performance. These resources can be derived from the intellectual capital component that is exploited in such a way as a competitive advantage.

Keywords: ASEAN Banking Sector; Competitive Advantage; Extended VAIC Plus; Financial Performance; Intellectual Capital

JEL Classification: G31; G32; G34

Citation: Rochmadhona, B. N., Suganda, T. R., \& Cahyadi, S. (2018). The competitive advantage between intellectual capital and financial performance of the banking sector in ASEAN. Jurnal Keuangan dan Perbankan, 22(2), 321-334. https://doi.org/10.26905/jkdp.v22i2.2060

\section{Abstrak}

Penelitian ini bertujuan untuk menguji efek mediasi dari competitive advantage dalam hubungan antara intellectual capital dan kinerja pada sektor perbankan di lima negara ASEAN. Selain itu, penelitian ini juga menganalisis perbedaan tingkat intellectual capital menggunakan komponennya yaitu human capital, structural capital, dan relational capital mengounakan model pengukuran Extended VAIC Plus (E-VAIC+). Penelitian ini menggunakan metode partial least square untuk menguji efek mediasi dan ANOVA untuk menouji perbedaan tingkat intellectual capital pada sektor perbankan di lima negara ASEAN. Hasil penelitian menunjukkan bahwa intellectual capital berpengaruh positifterhadap kinerja keuangan dan competitive advantage, competitive advantage berpengaruh positifterhadap kinerja keuangan, competitive advantage mempunyai pengaruh tidak langsung terhadap kinerja keuangan dan terdapat perbedaan tingkat intellectual capital pada Pndonesia, Laos, Vietnam, Filipina, dan Thailand. Hasil penelitian ini mendukung konsistensi resource based theory yang menyatakan bahwa kumpulan sumber daya yang unik yang dimiliki dan dikendalikan perusahaan dapat menjadikan perusahaan memiliki kinerja superior berkelanjutan. Sumber daya tersebut dapat berasal dari komponen intellectual capital yang dieksploitasi sedemikian rupa menjadi competitive advantage.

Kata Kunci: Sektor Perbankan ASEAN; Competitive Advantage; Extended VAIC Plus; Kinerja Keuangan; Intellectual Capital 
The emergence of intangible asset management practices with knowledge base is a result of changes in global economic conditions and the development of increasingly sophisticated information technology. Economic development has reached the formation of a single market and a single production center called the ASEAN Economic Community (AEC). The financial and banking sector react to the AEC by establishing the ASEAN Banking Integration Framework (ABIF) which is an inter-bank integration in ASEAN. ABIF is planned to be fully implemented by 2020 . ABIF's main objective is to provide market access, and operational flexibility in ASEAN member countries for Qualified ASEAN Banks (QAB), namely ASEAN banks that meet certain requirements has been mutually agreed upon by ASEAN. The requirements of banks to become candidates for QAB are ASEAN's strong capital banks, are highly resilient and well managed, and comply with prudential regulations by prevailing international standards. The banks are expected to be a driver of trade and investment in ASEAN (www.bi.go.id).

According to Cheng et al. (2010), intellectual capital is a key resource and drivers on performance and value creation, so that intellectual capital plays an important role in creating or maintaining a competitive advantage. Increased investment and management of strategic assets that are valuable, rare, and hard-to-imitate is the answer to competitive challenges. Competitive advantage is, thus, not dependent, as traditionally assumed, on such bases as natural resources, technology or economies of scale, since these are increasingly easy to imitate (Kamukama, 2013). They are indeed the assets which Stewart (1997) referred to as "invisible assets," which in a real sense are intellectual capital resources.

Ulum (2014) modify the advanced formula that is Extended VAIC Plus (E-VAIC+) which puts taxonomy of intellectual capital in a more appropriate position and have not been tested on the financial performance and the performance of the market. Therefore, this study aims to test the perfor- mance of intellectual capital by E-VAIC + method of financial performance using profitability ratios. If viewed from the perspective of resource-based theory, superior intellectual capital of the company is a good resource. The better the management of intellectual capital, then it will be better the performance of the company will be achieved (Ulum, 2016). E-VAIC+ adds a third component of intellectual capital not previously included in the VAIC model, which is customer capital efficiency (CCE). In addition, E-VAIC+ puts structural capital (SC) as its component, not part of human capital (HC) as in the Pulic model (2000) (Ulum, 2016).

Competitive advantage will make the company more valuable than its competitors in accordance with the resource-based theory proposed by Penrose (1959) is a company that has a unique competitive advantage. A company is said to have a competitive advantage if it can create higher economic value derived from its corporate resources than any other company in its industry (Porter, 1985). According to Pulic \& Kolakovic (2003), each company has unique knowledge, skills, values, and solutions (intangible resources) that can be transformed into market value. Therefore, competitive advantage is chosen as a mediator in this research between intellectual capital and financial performance.

Relationships, not just people, drive new sales and extend contracts. Thus, the relationship among employees is embodied in attributes like a shared code or a shared paradigm that facilitates a common understanding of collective goals and proper ways of acting in a social system (Kamukama \& Sulait, 2017). It is true that within an enterprise a set of common values helps firms to develop strong relationships that can erase the possibility of opportunistic behavior. Besides, the compatibility of individuals' values with an enterprise's values allows the employees to trust one another and pursue the collective goals by sharing knowledge and team working. It is this synergic effect that makes the 


\section{The Competitive Advantage between Intellectual Capital and Financial Performance of Banking Sector in ASEAN Bella Nursyarifa Rochmadhona, Tarsisius Renald Suganda, Sendy Cahyadi}

firm unique and enables it to build the firm's competitive position in the market (Bontis, 1998).

This is a comparative study of banking sector companies in five ASEAN countries namely Indonesia, Thailand, Philippines, Laos, and Vietnam. These countries are selected based on their legal system using the law system namely code law since the legal system of a country used will have an impact on the characteristics of a country's accounting policy. The purpose of this study is to examine the influence of intellectual capital on financial performance and competitive advantage, competitive advantage on financial performance and indirect effect of competitive advantage as a mediation variable between intellectual capital to financial performance. In addition, this study also aims to examine differences in the level of intellectual capital in banking companies in Indonesia, Thailand, Philippines, Laos, and Vietnam.

\section{HYPOTHESES DEVELOPMENT}

Intellectual capital can have a direct effect on assets owned by the company if it can manage its intellectual capital well (Lin \& Huang, 2011). Based on resource-based theory, excellent corporate performance is generated from the concept of intellectual capital. The higher the intellectual capital means, the higher the ability of the company's resource utilization in generating profit.

Companies can manage its resources effectively; it can create a competitive advantage compared to its competitors. Skilled human resources and high competence are a competitive advantage for the company. If the company can exploit and manage the potential of its employees well, then it can increase employee productivity. If the increased employee productivity, revenue, and profit the company will also increase. Increased revenue and profit can lead ROA companies are also increasing. So it can be concluded, if intellectual capital managed well by the company then can improve the company's financial performance (Widyaningdyah \& Aryani, 2013). The method of measuring intellectual capital used is the result of research conducted by Ulum (2014) that is E-VAIC+ which is suggested to be tested influence with financial performance. Based on the above statement then prepared the research hypothesis as follows:

$\mathrm{H}_{1}$ : intellectual capital has a positive effect on financial performance in the banking sector in Indonesia, Thailand, Philippines, Laos, and Vietnam

The resource-based theory proposed by Wernerfelt (1984) explains that the company that builds and controls its resources will have the ability to maintain its superiority if the company buys or obtains its resources from outside the organization. Companies are able to manage intellectual capital properly it will greatly affect the competitive advantage of the company, the higher the value of intellectual capital the greater the company's competitive advantage. This is according to research Anisah (2016) and Libyanita \& Wahidawati (2016) which showed that intellectual capital has a positive and significant impact on the company's competitive advantage. Competitive advantage is achieved by those firms that succeed in mobilizing their intellectual assets in the form of knowledge, technological skills, experience, and strategic capabilities (Kamukama \& Sulait, 2017).

According to Kamukama \& Sulait (2017) that it is important to note that competent staff, with unique qualities, can provide better services than their counterparts in the marketplace, which can put the firm in better competitive position. Teece (2000) and Zott (2003), who argued that organizations with superior manpower and learning capability are able to coordinate and combine their traditional resources and capabilities in new and distinctive ways to provide more value to their customers and, in general, to stakeholders than their competitors. This point of view is also consistent with Hamel \& 
Prahalad (2000), who argued that the best way to win in a competitive world is to build up long-term core competencies that can stand the test of time. Furthermore, strong internal processes, networks, and organizational culture can promote the firm's efficiency levels, which, in turn, can influence low costs and unique products in the market that may be difficult to be reproduced by others. Edvinsson \& Malone (1997), who established that organizational cultures, structures, and processes that support the purpose of the organization could promote efficiency, and thus, the firm's competitive advantage. Based on the above statement then prepared the research hypothesis as follows:

$\mathrm{H}_{2}$ : intellectual capital has a positive effect on competitive advantage on the banking sector in Indonesia, Thailand, Philippines, Laos, and Vietnam

Performance measurement is performed to determine achievement and purpose of the activity that has been carried out by the company within a certain period. Measurement of company performance can be measured by profitability ratios of ROA. Competitive advantage in resource-based theory is the creation of abnormal profit (Peteraf, 1993) or the level of above-average returns by utilizing the special features of the company (Lin \& Huang, 2011).

Cusumano, Kahl, \& Suarez (2010) shows the value of the capability ratios of managing the company's intangible assets with a higher competitive advantage than the company with a competitive disadvantage. This shows that companies can manage to sustain competitive advantage will be able to win the competition to obtain better financial performance than the competitors. Based on the above statement then prepared the research hypothesis as follows:

$\mathrm{H}_{3}$ : competitive advantage has a positive effect on financial performance in the banking sector in Indonesia, Thailand, Philippines, Laos, and Vietnam
Penrose (1959) states that companies will have a competitive advantage if they can manage resources well. Resources owned by companies, especially intellectual capital will greatly affect the company's performance in the future. This happens because when a company has intellectual capital, then it can prove that the company can manage resources well so that the company can have a competitive advantage from the management of these resources which then will be able to create the company's performance and the value of the company.

In the framework of resource-based theory, intellectual capital contributes to improving competitive advantage through value creation of resources and capabilities that are unique (Cheng et al., 2010). The more efficient for companies to manage intellectual capital, it will be faster to create a competitive advantage (Widyaningdyah \& Aryani, 2013). In the framework of RBT, intellectual capital contributes to improving competitive advantage through value creation of resources and capabilities that are unique (Cheng et al., 2010). The more efficient for companies to manage intellectual capital, it will be faster to create a competitive advantage (Firer \& Williams, 2003; Shiu, 2006; Coudhury, 2010; Khani et al., 2011). Supported by research conducted by Kamukama, Ahiauzu, \& Ntayi (2011), Anisah (2016), and Libyanita \& Wahidawati (2016) stated that competitive advantage of the company could be a mediating variable between intellectual capital and company performance. Based on the above statement then prepared the research hypothesis as follows:

$\mathrm{H}_{4}$ : competitive advantage has an indirect effect between intellectual capital and financial performance in the banking sector in Indonesia, Thailand, Philippines, Laos, and Vietnam

The difference in the use of the legal system of a country will have an impact on the characteristics of a country's accounting policies. This is due to the accounting policy of a country is strongly influenced by stakeholders who have the characteristics 


\section{The Competitive Advantage between Intellectual Capital and Financial Performance of Banking Sector in ASEAN Bella Nursyarifa Rochmadhona, Tarsisius Renald Suganda, Sendy Cahyadi}

of a legal system. Theoretically, it is known that the four dominant legal systems of the world are code law or civil law, common law, Islamic law, and social law. However, the more dominant legal system used in the international world is only two, namely the legal code law and common law. The common law legal system, the accounting rules developed by the standard compilers while in the code law system provides a detailed accounting. The legal system code law is a legal system of the oldest and most influential is the Romano-Germanic legal system with the accounting system in continental European form. This legal system is widely applied in European countries and its former colonies. On the other hand, the common law system or the AngloSaxon legal system applied in the United Kingdom and countries of the former colonies (La Porta et al., 1998).

Good accounting standards and stakeholder protection measures are associated with a lower concentration of ownership, indicating that concentration is indeed a response to poor investor protection. Common law has stronger and better stakeholder protection because it is based on fairness, duty, and honesty, compared to code law whose system is controlled by a legislature that is more based on statues. Countries that protect stakeholders have more valuable stock markets, larger numbers of listed securities per capita, and a higher rate of IPO (initial public offering) activity than do the unprotective countries (La Porta et al., 2000). This indicates that the code law tends to be more prescriptive and procedural for example management or board of directors governing firms represents multiple stakeholder interests (e.g., debt holders, employees, suppliers, customers, shareholders, and government) so stakeholders have a more broadly and may affect the creation and performance of intellectual capital companies because the intellectual capital component also consists of stakeholders from within and outside the company. On the basis of the above then compiled following research hypotheses:
$\mathrm{H}_{5}$ : the performance of intellectual capital in the banking sector in Indonesia, Thailand, Philippines, Laos, and Vietnam is different

\section{METHODS}

This research is quantitative research using secondary data obtained from published financial statements. The financial statements collected from Jakarta Stock Exchange (JKSE), Stock Exchange of Thailand Index (SET), Philippine Stock Exchange Index (PSEI), Lao Securities Exchange (LSX), and Hochiminh Stock Exchange (HSX). The population used in this research is the banking sector companies in five ASEAN countries registered in the capital market in the period 2015-2016. The sample in this research is a banking sector company in five ASEAN countries that adopt law system namely code law that is Indonesia, Thailand, Philippines, Laos, and Vietnam. The terms indicated for the company that can be used as a sample, as follows, companies of the banking sector are listed in the capital markets of Indonesia, Thailand, Philippines, Laos, and Vietnam during the year 2015-2016 and companies that publish audited financial statements of the year 2015-2016.

\section{Operational Definitions of Variables}

\section{Return on Assets}

ROA is a ratio that assesses the ability of companies to earn profits from current assets or noncurrent. This ratio is the ratio that compares net income to total assets. The higher the value of this ratio indicates that the company is able to utilize the asset in the company's net profit (Brigham \& Houston, 2016).

$\mathrm{ROA}=\frac{\text { Net Income }}{\text { Total Assets }}$ 


\section{Intellectual capital}

E-VAIC + adds a third component of intellectual capital not previously included in the VAIC model, which is customer capital efficiency (CCE). In addition, E-VAIC + puts structural capital (SC) as its own component, not part of human capital (HC) as in the Pulic model (2000) (Ulum, 2016). The formulation of E-VAIC + according to Ulum (2016) comprises the following.

Value Added (VA), shows the company's ability in value creation.

$\mathrm{VA}=\mathrm{OP}+\mathrm{EC}+\mathrm{D}+\mathrm{A}$

Description:

OP : operating profit

EC : employee cost

D : depreciation

A : amortizations

Human Capital Efficiency (HCE), shows the contribution of the company's value added to those made by each rupiah invested in HC.

$\mathrm{HCE}=\frac{\mathrm{VA}}{\mathrm{HC}}$

Description:

VA : value added

HC : human capital; total expenses for employees

Innovation Capital Efficiency (InCE), shows the contribution of development and innovation invested in R \& D expenditures to value added.

$\ln C E=\frac{\ln C}{V A}$

Description:

InC : innovation capital; R\&D cost

VA : value added
Process Capital Efficiency (PCE), shows the combined value of a company's value creation process.

$\mathrm{PCE}=\frac{\mathrm{PC}}{\mathrm{VA}}$

Description:

PC : process capital; depreciation and amortiza tion costs

VA : value added

Structural Capital Efficiency (SCE), shows the contribution of infrastructure and company resources that support employee productivity.

$\mathrm{SCE}=\operatorname{InCE}+\mathrm{PCE}$

Description:

InCE : innovation capital efficiency

PCE : process capital efficiency

Relational Capital Efficiency (RCE), show relationship of company and consumer to company value added.

$\mathrm{RCE}=\frac{\mathrm{RC}}{\mathrm{VA}}$

Description:

RC : relational capital; marketing costs

VA : value added

Intellectual Capital Efficiency (ICE), shows a collection of uses of capabilities, knowledge, information, relationships, and experiences as intellectual property.

$\mathrm{ICE}=\mathrm{HCE}+\mathrm{SCE}+\mathrm{RCE}$

Description:

HCE : human capital efficiency

SCE : structural capital efficiency

RCE : relational capital efficiency 
Capital Employed Efficiency (CEE), shows the contribution of the company's value added to the resources or assets owned by the company.

$\mathrm{CEE}=\frac{\mathrm{VA}}{\mathrm{CE}}$

Description:

VA: value added

CE : capital employed; book value of total assets

Extended VAIC Plus (E-VAIC+), indicates the intellectual ability of the organization,

$\mathrm{E}-\mathrm{VAIC}+=\mathrm{ICE}+\mathrm{CEE}$

Description:

ICE : intellectual capital efficiency

CEE : capital employed efficiency

Intellectual capital company with E-VAIC+ method into 4 categories (Ulum, 2014), as follows:

Top performers - E-VAIC + score above 3,5

Good performers - E-VAIC + score between 2,5 to 3,49

Common performers - E-VAIC + score between 1,5 to 2,49

Bad performers - E-VAIC score below 1.5

\section{Competitive Advantage}

Source of competitive advantage by Cusumano, Kahl, \& Suarez (2010) divided into four, namely customer relationships, supplier relationships, intellectual property, and fixed asset management. Cusumano, Kahl, \& Suarez (2015) proved mathematically that the combination of the ratios that is a proxy of the relationship with customers, suppliers, proxy intellectual property, and the management of fixed assets would form a new ratio called as Du Pont Identity or known as ROIC (Return on Invested Capital). Meanwhile, Lin \& Huang (2011) proves that companies that have a competitive advantage through light-assets rating models will produce a more superior performance that also uses Return on Invested Capital (ROIC) indicators on semiconductor manufacturing companies. The competitive advantage variables are measured using ROIC in a business attempts to measure the return earned on capital invested in an investment (Damodaran, 2007) with the following formula.

ROIC $=\frac{\text { NOPLAT }}{\text { IC }}=\frac{(S-\text { CGS }- \text { Adv }- \text { R\&D }- \text { Dep }- \text { SG\&A }- \text { tax })}{(\text { FA }+ \text { AR }+ \text { Inv }- \text { AP }+ \text { cash })}$

Description:

ROIC : return on invested capital

NOPLAT : net operating income less adjusted tax (or equivalent to net profit after tax)

IC : invested capital

S : sales

CGS : cost of goods sold

Adv : advertising expenses

R\&D : research and development expenditure

Dep : depreciation expenses

SG\&A : selling, general, and administration expenses

Tax $\quad: \operatorname{tax}$

FA : fixed assets

AR : account receivable

Inv : inventory

AP : account payable

cash : cash

The method of analysis used in this study is path analysis and ANOVA. Path analysis was conducted to see the effect of directly or indirectly influence the dependent variable and the independent variables to be mediated by a mediator variable (Ulum, Ghozali, \& Chariri, 2008; Ulum, 2013; Ulum, Ghozali, \& Purwanto, 2014). Testing this path analy- 
sis using partial least square with WarpPLS statistical application, while for the difference test using SPSS statistical application with ANOVA test.

In addition, this study uses control variables to examine the relationship between intellectual capital to competitive advantage and financial performance, there are two control variables that refer to Young et al. (2009), i.e., Loan Quality (LQ) and Gross Domestic Product (GDP). This study adopts the ratio of the allowance for loan losses to the total of the bank's loans to measure a bank's LQ. The poorer a bank's LQ, the higher are the chances that it will incur loan losses and its VA will also be lower. Market information and financial performance are primarily captured in local currencies. Thus, there is a need to control for the cross-country variation in exchange and economic growth. GDP is the most frequently used indicator of market activity and is most often measured on an annual or quarterly basis to gauge the growth of a country's economic activity between one period and another.

\section{RESULTS}

There are 54 companies in the banking sector in five ASEAN countries sampled in this study. The following is the result of the influence of intellectual capital, competitive advantage, and financial performance using partial least square.

Multiple regression analysis is used to test these two sets of hypotheses. Financial performance is used as a dependent variable with intellectual capital and competitive advantage as an independent variable. Two control variables, which are LQ and GDP are also included in the analysis according to their potential effects on financial performance. In each hypothesis, there are two multiple regression models specified. The multiple regression models are displayed as follows:

Fin Perf $=\alpha+\beta 1$ IC $+\beta 2 \mathrm{LQ}+\beta 3 \mathrm{GDP}+\mathrm{e}$

ComAdv $=\alpha+\beta 1$ IC $+\beta 2 \mathrm{LQ}+\beta 3 \mathrm{GDP}+\mathrm{e}$

Fin Perf $=\alpha+\beta 1$ IC $+\beta 2$ ComAdv $+\beta 3 \mathrm{LQ}+\beta 4$ GDP $+\mathrm{e}$

Table 1 illustrates results of the multiple regression analysis. The interpretation of the regression result for hypothesis 1,2 , and $3 . \mathrm{H}_{1}$ shows that intellectual capital to financial performance has a significant positive effect of 0.323 with a p-value less than 0.001 or 1 percent and effect size that $0.09>$ 0.02 as a show that intellectual capital has a significant effect to financial performance. $\mathrm{H}_{2}$ shows that intellectual capital has the significantly positive effect on competitive advantage ( 0.188 with a p-value less than 0.001). The effect size shows that intellectual capital has a significant effect on competitive advantage $(0.038>0.02) . \mathrm{H}_{3}$ shows that competitive advantage has a significantly positive effect on financial performance ( 0.233 with p-value 0.006$)$, intellectual capital has a significantly positive effect on financial performance $(0.323$ with a p-value less than 0.001). The effect size shows that intellectual capital has a significant effect on financial performance $(0.13>0.02)$.

Table 1. The result of Multiple Regression

\begin{tabular}{|c|c|c|c|c|c|c|}
\hline \multirow[t]{2}{*}{$\begin{array}{l}\text { Independent } \\
\text { Variable }\end{array}$} & \multicolumn{2}{|c|}{$\begin{array}{l}\text { Dependent Variable: Fin.Perf } \\
\qquad \mathbf{H}_{1}\end{array}$} & \multicolumn{2}{|c|}{$\begin{array}{c}\text { Dependent Variable: } \\
\text { Com.Adv } \\
\mathrm{H}_{2}\end{array}$} & \multicolumn{2}{|c|}{$\begin{array}{l}\text { Dependent Variable: Fin.Perf } \\
\qquad \mathrm{H}_{3}\end{array}$} \\
\hline & B & p-value & B & p-value & B & p-value \\
\hline In.Cap & 0.323 & $<0.001$ & 0.188 & $<0.001$ & 0.323 & $<0.001$ \\
\hline Com.Adv & & & & & 0.233 & 0.006 \\
\hline LQ & -0.276 & 0.001 & -0.152 & 0.051 & -0.276 & 0.001 \\
\hline GDP & 0.322 & $<0.001$ & 0.173 & 0.032 & 0.322 & $<0.001$ \\
\hline Effect Size & & 0.09 & & 0.038 & & 0.13 \\
\hline
\end{tabular}




\section{The Competitive Advantage between Intellectual Capital and Financial Performance of Banking Sector in ASEAN Bella Nursyarifa Rochmadhona, Tarsisius Renald Suganda, Sendy Cahyadi}

Table 1 shows GDP appears to be a significant control variable in most regression models, and LQ found to possess less significant control influence, although it has a p-value that is not much different.

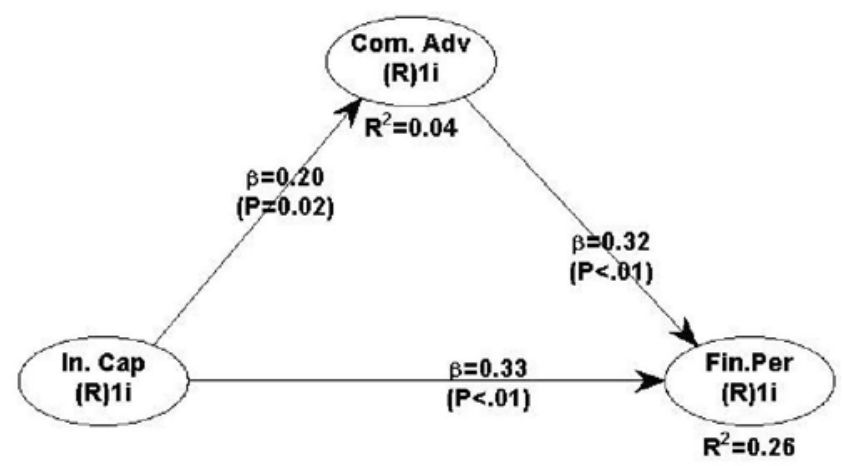

Figure 1. Path Diagram

$V A F=\frac{a \times b}{a \times b+c}=\frac{0,200 \times 0,315}{0,200 \times 0,315+0,335}=0,461$ or $46,1 \%$

Table 2. Criteria Variance Accounted For (VAF)

\begin{tabular}{ll}
\hline Criteria & Rule of Thumb \\
\hline VAF $<20 \%$ & No mediation effect \\
$20 \% \leq \mathrm{VAF} \leq 80 \%$ & Partial mediation \\
$\mathrm{VAF}>80 \%$ & Full mediation \\
\hline
\end{tabular}

Source: Solihin \& Ratmono (2013)

Hypothesis 4 is shown through variance accounted for (VAF) shows that equal to 0.461 or 46.1 percent. It can be said that competitive advantage has an indirect effect of intellectual capital on partial mediation financial performance in accordance with the criteria in Table 2 if the VAF value between 20 percent and 80 percent indicates partial mediation.

Hypothesis 5 shows that there is a difference in intellectual capital between Indonesia, Laos, Vietnam, Philippines, and Thailand. It can be shown with the Table 3 and Figure 2.

In Table 3 there is a mean difference column for variables are Extended VAIC Plus, human capi- tal efficiency, structural capital efficiency, relational capital efficiency, and capital employed efficiency if there is an asterisk $\left(^{*}\right)$ in the mean difference, it can be said that there is a difference in the group of countries. There are asterisks $\left(^{*}\right)$ in mean difference column variable of E-VAIC + (Extended VAIC Plus) reveals that differences are between Indonesia and Vietnam, Indonesia and Philippines, and between Indonesia and Thailand. This shows that there is differences value of E-VAIC+ between Indonesia, Vietnam, Philippines, and Thailand. Indonesia's mean difference column to Vietnam, Philippines, and Thailand show a negative value indicating that the mean E-VAIC+ of Indonesia is lower than Vietnam, Philippines, and Thailand.

Human capital efficiency have a significant difference between countries are Indonesia and Vietnam, Indonesia, and the Philippines, and between Indonesia and Thailand. This shows that there is differences value of HCE between Indonesia, Vietnam, Philippines, and Thailand. Indonesia's mean difference column to Vietnam, Philippines, and Thailand show a negative value indicating that the mean HCE of Indonesia is lower than Vietnam, Philippines, and Thailand.

Structural capital efficiency has a significant difference between countries are Thailand and Indonesia, Thailand and Laos, Thailand and Vietnam, Thailand and Filipina, Filipina and Indonesia, and between Filipina and Vietnam. This shows that there is differences value of SCE between Thailand to Indonesia, Laos, Vietnam, and the Philippines, and between the Philippines to Indonesia and Vietnam. Thailand's mean difference column to Indonesia, Laos, Vietnam, and the Philippines shows a negative value indicating that the mean SCE of Thailand is lower than Indonesia, Laos, Vietnam, and Filipina. Whereas, Philippines's mean difference column to Indonesia and Vietnam shows a positive value indicating that the mean SCE of Philippines is higher than Indonesia and Vietnam. 


\section{Jurnal Keuangan dan Perbankan | PERBANKAN}

Vol. 22, No. 2, April 2018: 321-334

Table 3. Output Tuckey Multiple Comparisons

\begin{tabular}{|c|c|c|c|c|c|c|}
\hline \multirow{3}{*}{ Countries } & & \multicolumn{5}{|c|}{ Mean Difference } \\
\hline & & \multirow{2}{*}{$\begin{array}{c}\text { Extended VAIC } \\
\text { Plus }\end{array}$} & \multirow{3}{*}{$\begin{array}{c}\text { Human } \\
\text { Capital } \\
\text { Efficiency }\end{array}$} & \multirow{2}{*}{$\begin{array}{c}\text { Structural } \\
\text { Capital } \\
\text { Efficiency }\end{array}$} & \multirow{2}{*}{$\begin{array}{c}\text { Relational } \\
\text { Capital } \\
\text { Efficiency }\end{array}$} & \multirow{2}{*}{$\begin{array}{c}\text { Capital } \\
\text { Employed } \\
\text { Efficiency }\end{array}$} \\
\hline & & & & & & \\
\hline \multirow{4}{*}{ Indonesia } & Laos & -.1961897 & & -.1011397 & .0172500 & .0197810 \\
\hline & Vietnam & $-1.3933147^{*}$ & -1.3103750 & .0184978 & $.0190250^{*}$ & .0116685 \\
\hline & Philippines & $-.7848050^{*}$ & -.5785154 & $-.0861666^{*}$ & .0044962 & .0074541 \\
\hline & Thailand & $-.8230468^{*}$ & -.9419500 & $.2208246^{*}$ & $.0217714^{*}$ & .0083239 \\
\hline \multirow{4}{*}{ Laos } & Laos & .1961897 & $1.4424009^{*}$ & 1011397 & -.0172500 & -.0197810 \\
\hline & Vietnam & -1.1971250 & 1.3103750 & .1196375 & .0017750 & -.0081125 \\
\hline & Philippines & -.5886154 & .7318596 & .0149731 & -.0127538 & -.0123269 \\
\hline & Thailand & -.6268571 & .3684250 & $.3219643^{*}$ & .0045214 & -.0114571 \\
\hline \multirow{4}{*}{ Vietnam } & Laos & $1.3933147^{*}$ & $.7105412^{*}$ & -.0184978 & $-.0190250^{*}$ & -.0116685 \\
\hline & Vietnam & 1.1971250 & .5785154 & -.1196375 & -.0017750 & .0081125 \\
\hline & Philippines & .6085096 & -.7318596 & $-.1046644^{*}$ & -.0145288 & -.0042144 \\
\hline & Thailand & .5702679 & -.3634346 & $.2023268^{*}$ & .0027464 & -.0033446 \\
\hline \multirow{4}{*}{ Philippines } & Laos & $.7848050^{*}$ & $1.0739759^{*}$ & $.0861666^{*}$ & -.0044962 & -.0074541 \\
\hline & Vietnam & .5886154 & .9419500 & -.0149731 & .0127538 & .0123269 \\
\hline & Philippines & -.6085096 & -.3684250 & $.1046644^{*}$ & .0145288 & .0042144 \\
\hline & Thailand & -.0382418 & .3634346 & $.3069912^{*}$ & $.0172753^{*}$ & .0008698 \\
\hline \multirow{4}{*}{ Thailand } & Laos & $.8230468^{*}$ & .1320259 & $-.2208246^{*}$ & $-.0217714^{*}$ & -.0083239 \\
\hline & Vietnam & .6268571 & -1.3103750 & $-.3219643^{*}$ & -.0045214 & .0114571 \\
\hline & Philippines & -.5702679 & -.5785154 & $-.2023268^{*}$ & -.0027464 & .0033446 \\
\hline & Thailand & .0382418 & -.9419500 & $-.3069912^{*}$ & $-.0172753^{*}$ & -.0008698 \\
\hline
\end{tabular}

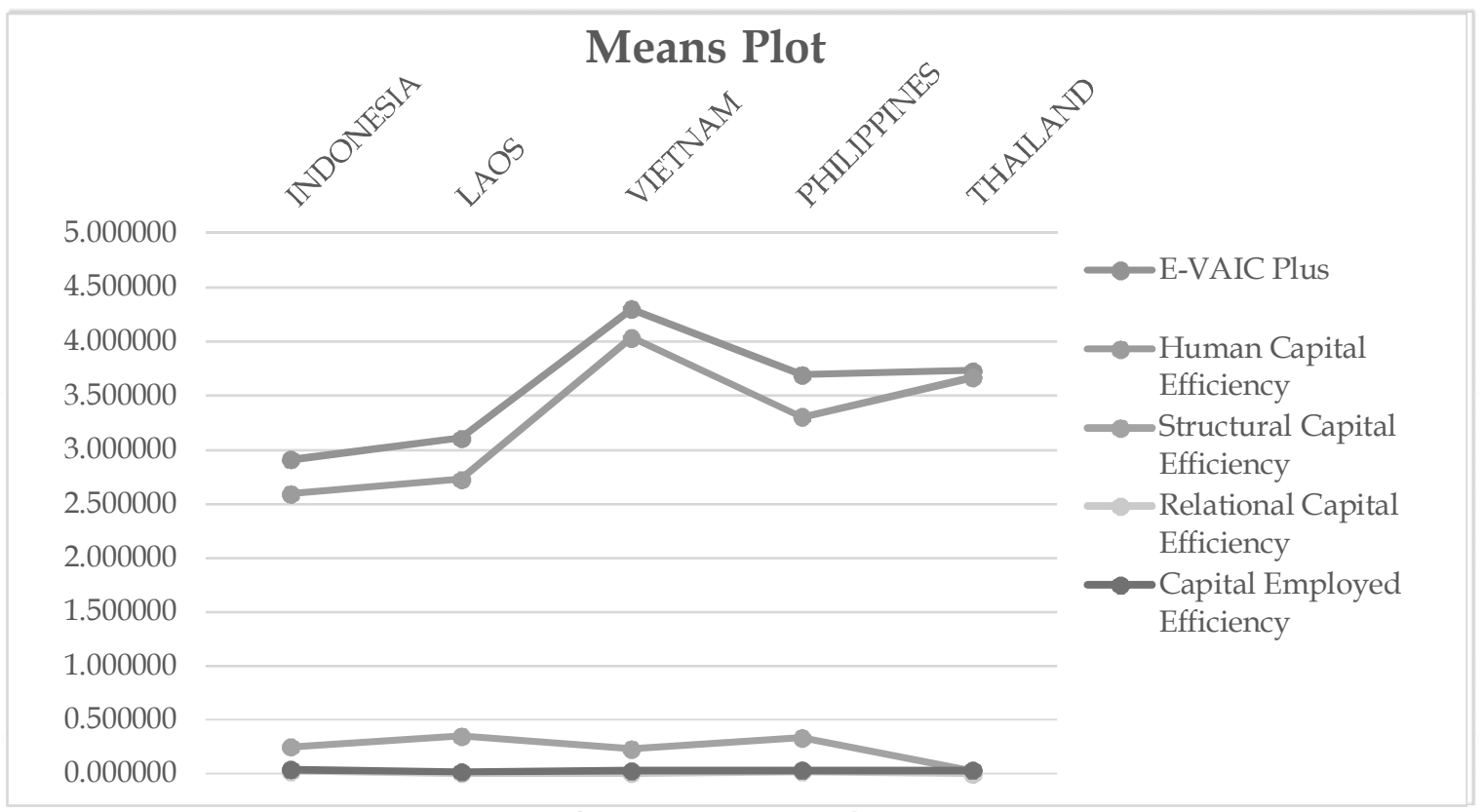

Figure 2. Means Plot 


\section{The Competitive Advantage between Intellectual Capital and Financial Performance of Banking Sector in ASEAN Bella Nursyarifa Rochmadhona, Tarsisius Renald Suganda, Sendy Cahyadi}

Relational capital efficiency has a significant difference between countries are Indonesia and Vietnam, Indonesia and Thailand, and between Filipina and Thailand. This shows that there is differences value of RCE between Indonesia, Vietnam, Philippines, and Thailand. Indonesia's mean difference column to Vietnam and Thailand, and between the Philippines and Thailand shows a positive value indicating that the mean RCE of Indonesia is higher than Vietnam and Thailand, and the mean RCE of Philippines is higher than Thailand.

Capital Employed Efficiency has no a significant difference between five ASEAN countries because in the column mean difference there is no asterisk $\left(^{*}\right)$. This shows that there is no difference value of CEE between Indonesia, Laos, Vietnam, Philippines, and Thailand.

If classified into 4 categories according to (Ulum, 2014), then the performance of intellectual capital with E-VAIC+ model based on the mean of each country, which can be categorized to top performers if sorted from the highest mean of the countries of Vietnam, Thailand, and the Philippines. While the category of a good performer is Laos and the last one is Indonesia. HCE mean rank is Vietnam, Thailand, Philippines, Laos, and Indonesia. Meanwhile, SCE mean rank is Laos, Philippines, Indonesia, Vietnam, and Thailand. RCE mean rank is Indonesia, Philippines, Laos, Vietnam, and Thailand. Last, CEE mean rank is Indonesia, Philippines, Thailand, Vietnam, and Laos.

\section{DISCUSSION}

The results of this study support research conducted by Anisah (2016) and Libyanita \& Wahidawati (2016). Intellectual capital owned by a company is an asset that can directly affect the company to run effectively and efficiently. Companies that can utilize intellectual capital well will be able to improve the company's financial performance as reflected in the profit. Intellectual capital will be a competitive advantage if a company can manage well so that it can provide added value for the stakeholders. Intellectual capital according to (Cheng et al., 2010) is a key resource and driver for performance and value creation, so that intellectual capital plays an important role in creating and maintaining a competitive advantage. Therefore, competitive advantage has an indirect effect between intellectual capital and financial performance as well as the company will be more valuable.

The results of this study prove that the intellectual capital owned by the company can make the company has sustained competitive advantage so that the company can be more valuable and able to compete with its competitors, and can improve the company's financial performance, in this case, is profit. This supports the research conducted by Kamukama, Ahiauzu, \& Ntayi (2011) that the uniqueness of intellectual capital which is one asset in the organization of the company can make the organization has a better competitive advantage position. However, contrary to research conducted by Ihsan \& Zacky (2016) and Yanwari (2016) that the existence of intellectual capital has no direct contribution for investors to make investment decisions, and only as leverage of financial performance that indirectly resulted in a spurred market reaction. So there is an indication of the use of physical and financial assets still dominate to contribute to the financial performance of the company.

The result of regression by using control variable shows the lower the loan quality, the higher the financial performance and competitive advantage of the company. It is happening because the allowance for loan losses of the bank is low and can increase value creation (Young et al., 2009). LQ and GDP can control the influence of intellectual capital on the financial performance and competitive advantage. This is happening because loans are the primary business of a bank and for profit maximization; if LQ is high then the banks have low capital relational to its customers. Meanwhile, if a country 
has a low GDP, then it will have an impact on the economic crisis (bankruptcy in banks) because customers cannot pay the loan and withdraw funds from the bank.

In practice, the company's intellectual capital of human capital is a resource that comes from knowledge, skills, expertise, and competence in innovation which may be invested by Vietnam to have a higher value of HCE. Firms in Laos may create value by focusing structural capital to sustain their ability of organizations to reach the market, hardware, software, databases, organizational structure, patent, trademark, and all the organization's ability to support employee productivity.

Furthermore, relational capital is a resource of knowledge in order to create relationships with a range of markets, customers, suppliers, governments, and industry associations may concern firms in Indonesia by developing an implementation of supplier and customer selection program to have a higher value of RCE. A result such differ with research by (Nimtrakoon, 2015) which shows that the highest HCE, SCE, and RCE are achieved by Indonesia, while the highest CEE is achieved by Singapore. It can directly contribute to financial performance, in this case, is the creation of corporate profits. This is certainly considered good because when companies do business for the creation of intellectual capital will certainly require a considerable cost of hope that can be used as a competitive advantage. Resources that serve as a competitive advantage can be classified into resource heterogeneity and immobility that can be used as capital to compete with its competitors. Therefore, when a company earns a high profit resulting from intellectual capital and competitive advantage, it can be said that the company succeeds in creating superior sustainable performance.

The results of ANOVA test of intellectual capital in the banking company in Indonesia, Laos, Vietnam, Philippines, and Thailand in the framework of the ASEAN Economic Community (AEC) in 2015 and ASEAN Banking Integration Framework (ABIF) in 2020 showed that there were differences of intellectual capital in the model E-VAIC Plus, HCE, SCE, $\mathrm{RCE}$, and CEE with rank order results based on the mean of the highest countries, i.e., Vietnam, Thailand, Philippines, Laos, and Indonesia. But, if the performance of intellectual capital is very important for banking companies because in the framework of the ASEAN Banking Integration Framework (ABIF) in 2020, there is a requirement to enter the Qualified ASEAN Banks (QAB) which is the main objective of the establishment of ABIF to enable banking companies to expand into the ASEAN market, and banking companies by Ulum (2016) will be more focused on intellectual capital productivity through more than those of companies in other sectors.

\section{CONCLUSION AND SUGGESTIONS}

\section{Conclusion}

Based on the research that has been done, the findings are that intellectual capital has a positive effect on financial performance, intellectual capital has a positive effect on competitive advantage, competitive advantage has an effect on financial performance, competitive advantage has indirect influence between intellectual capital to financial performance, intellectual capital performance of banking sector in Indonesia, Laos, Vietnam, Philippines, and Thailand is different. Thus, the alternative hypothesis accepted or intellectual capital affects the financial performance and mediated by competitive advantage in the banking sector companies in Indonesia, Laos, Vietnam, Philippines, and Thailand.

\section{Suggestions}

Research suggestions for the company are expected to maintain and even increase its resources, which will affect the performance of intellectual capital that is held for ASEAN Banking Integration Framework (ABIF) in 2020 and to be included in the Qualified ASEAN Banks (QAB). In addition, 


\section{The Competitive Advantage between Intellectual Capital and Financial Performance of Banking Sector in ASEAN}

Bella Nursyarifa Rochmadhona, Tarsisius Renald Suganda, Sendy Cabyadi

suggestions the next researcher is to assess the performance of intellectual capital and competitive advantage qualitatively in order to classify intellectual capital assets that can be used as different com- petitive advantages compared to competitors so that it can generate a group of resource heterogeneity and/or resource immobility.

\section{REFERENCES}

Anisah, R. N. (2016). The effect of intellectual capital toward company financial performance with competitive advantage as intervening variable. Jurnal Akuntansi $\mathcal{E}$ Investasi, 17(2), 215-226.

Bontis, N. (1998). Intellectual capital: An exploratory study that develops measures and models. Journal Management Decision, 36(2), 63-76.

Brigham, E. F., \& Houston, J. F. (2016). Dasar-dasar Manajemen Keuangan. Jakarta: Salemba Empat.

Cheng, M. Y., Lin, J. Y., Hsiao, T. Y., \& Lin, T. W. (2010). Invested resource, competitive intellectual capital, and corporate performance. Journal of Intellectual Capital, 11(4), 433-450. https:/ / d o i.org / 10.1108 / 14691931011085623.

Choudhury, J. (2010). Performance Impact of Intellectual Capital: A Study of Indian it Sector. International Journal of Business and Management, 5(9): 72-80. http:/ /dx.doi.org / 10.5539 / ijbm.v5n9p72.

Cusumano, M. A., Kahl, S. J., \& Suarez, F. F. (2015). Services, industry evolution, and the competitive strategies of product firms. Strategic Management Journal, 36(4), 559-575. https://doi.org/ 10.1002/smj. 2235.
Damodaran, A. (2007). Return on capital (ROC), return on invested capital (ROIC) and return on equity (ROE): Measurement and implications. New York University: Stern School of Business, 1-69. http://dx.doi.org/ 10.2139/ssrn.1105499.

Edvinsson, L., \& Malone, M. S. (1997). Intellectual Capital: Realizing Your Company's True Value by Finding Its Hidden Brainpower. New York: Harper Col.

Firer, S., \& Williams, S. M. (2003). Intellectual capital and traditional measures of corporate performance. Journal of Intellectual Capital, 4(3), 348-360. https://doi.org/10.1108/ 14691930310487806

Hamel, G., \& Prahalad, C. K. (2000). Kompetisi Masa Depan; StrategiStrategi Terobosan untuk Merebut Kendali atas Industri Anda dan Menciptakan Pasar Masa Depan. Jakarta: Binarupa.

Ihsan, M., \& Zacky, A. (2016). The effect of intellectual capital to financial performance and the consequences to market value. Jurnal Akuntansi, 3(4), 56-71.

Khani, A., Hosain, A., Ahmadi, F., \& Homayouni, G. (2011). The impact of intellectual capital on performance of Iranian food firms. Interdisciplinary Journal of Contemporary Research in Business, 2(10), 315-326.

Kamukama, N. (2013). Intellectual capital: Company's invisible source of competitive advantage. Competitiveness Review, 23(3), 260-283. https:// d o i . o r g / 10.1108 / 10595421311319834.

Kamukama, N., Ahiauzu, A., \& Ntayi, J. M. (2011). Competitive advantage: Mediator of intellectual capital and performance. Journal of Intellectual Capital, 12(1), 152-164. https://doi.org/ 10.1108/14691931111097953.

Kamukama, N., \& Sulait, T. (2017). Intellectual capital and competitive advantage in Uganda's microfinance industry. African Journal of Economic and Management Studies, 8(4), 498-514. https://doi.org/10.1108/ AJEMS-02-2017-0021.

Libyanita, M., \& Wahidawati. (2016). The effect of intellectual capital to financial performance on banking sector. Jurnal Ilmu $\mathcal{E}$ Riset Akuntansi, 5(6), 1-19.

Lin, C. -S., \& Huang, C. -P. (2011). Measuring competitive advantage with an asset-light valuation model. African Journal of Business Management, 5(13), 51005108. https://doi.org/10.5897/ AJBM10.681.

Nimtrakoon, S. (2015). The relationship between intellectual capital, firms' market value, and financial performance: Empirical evidence from the ASEAN. Journal of Intellectual Capital, 16(3), 587-618. https:// doi.org/10.1108/JIC-09-20140104. 
Penrose, E. (1959) The Theory of the Growth of the Firm. Great Britain: Basil Blackwell \& Mott Ltd.

Peteraf, M. A. (1993). The cornerstones of competitive advantage: A resource-based view. Strategic Management Journal, 14(3), 179_ 191.

La Porta, R., Lopez-de-Silanes, F., Shleifer, A., Vishny, R. W. (1998). Law and finance. Journal of Political Economy, 106(6), 1113-1155. https://doi.org/ $10.1086 / 250042$.

La Porta, R., Lopez-de-Silanes, F., Shleifer, A., Vishny, R. W. (2000). Investor protection and corporate governance. Journal of Financial Economics, 58(1-2), 327. https://doi.org/10.1016/ S0304-405X(00)00065-9.

Porter, M. E. (1985) Competitive Advantage. New York: The Free Press.

Pulic, A., \& Kolakovic, M. (2003). Value creation efficiency in the new economy. Global Business and Economics Review, 5(1), 111. https:// doi.org/10.1504/ GBER.2003.006201.

Solihin, M., \& Ratmono, D. (2013). Analysis of SEM-PLS with WarpPLS 3.0 for Nonlinear Relations in Social and Business Research. Yogyakarta: Andi.

Shiu, H. J. (2006). The application of the value added intellectual coefficient to measure corporate performance: evidence from technological firms. Interna- tional Journal of Management, 23(2), 356-65.

Stewart, T. A. (1997). Intellectual capital: The New Wealth of Organizations. London: Nicholas Brealey Publishing.

Teece, D. J. (2000). Strategies for managing knowledge assets: the role of ûrm structure and industrial context. Long Range Planning, 33(1), 35-54.

Ulum, I. (2013). Pengaruh intellectual capital terhadap kinerja keuangan perusahaan perbankan di Indonesia. Jurnal Akuntansi, 13, 833-862.

Ulum, I. (2014). Extended VAIC Plus (EVAIC+); A comprehensive measurement model of intellectual capital performance. Paper presented at the 1st International Conference on Future Business Environment and Innovation.

Ulum, I. (2016). Intellectual capital measurement model, disclosure framework, and organizational performance. Malang: UMM Press.

Ulum, I., Ghozali, I., \& Chariri, A. (2008). Intellectual capital dan kinerja keuangan perusahaan; Suatu analisis dengan pendekatan partial least squares. Jurnal Akuntansi \& Investasi, 9(2), 138-158.

Ulum, I., Ghozali, I., \& Purwanto, A. (2014). Intellectual capital performance of Indonesian banking sector: A modified VAIC (M-VAIC) perspective. Asian Journal of Finance $\mathcal{E}$ Accounting,
6(2), 103. https:// doi.org/ 10.5296/ajfa.v6i2.5246.

Wernerfelt, B. (1984). A Resourcebased view of the firm. Strategic Management Journal, 5(2), 171180. https://doi.org/10.1002/ smj. 4250050207

Widyaningdyah, A. U., \& Aryani, Y. A. (2013). Intellectual capital and competitive advantage (Empirical study on manufacturing companies Jakarta Stock Industrial ClassificationJASICA). Jurnal Akuntansi dan Keuangan, 15(1), 1-14. https:/ /doi.org/10.9744/jak.15.1.114.

Yanwari, R. (2016). Analysis of effect of intellectual capital and capital structure of the company's financial performance award recipient Indonesian study years 2011-2014. Jurnal Riset Akuntansi, 2(4), 86-100.

Young, C. -S., Su, H. Y., Fang, S. C., \& Fang, S. R. (2009). Cross-country comparison of intellectual capital performance of commercial banks in Asian economies. The Service Industries Journal, 29(11), 1565-1579. https:/ / d o i.org/10.1080/ 02642060902793284 .

Zott, C. (2003). Dynamic capabilities and the emergence of intraindustry differential firm performance: Insights from a simulation study. Strategic Management Journal, 24(2), 97-125. https://doi.org/10.1002/ smj.288. 